\title{
Autologous Serum Treatment in the Dry Eye Syndrome: A Case Report
}

\author{
Dilan Yıldız ${ }^{1}$, Gamze Maden ${ }^{1}$, Serap Yurttaşer Ocak ${ }^{1}$, Mehmet Egemen Karataş ${ }^{2}$ and Mustafa Nuri Elçioğlü \\ ${ }^{1}$ Department of Ophthalmology, Okmeydani Training and Research Hospital, Turkey \\ ${ }^{2}$ Department of Ophthalmology, Sisli Hamidiye Etfal Training and Research Hospital, Turkey
}

Submission: August 03, 2017; Published: September 19, 2018

*Corresponding author: Gamze Maden, Department of Ophthalmology, Okmeydani Training and Research Hospital, Istanbul, Turkey, Tel: +90 5062993457; Email: madengamze14@gmail.com

\begin{abstract}
Aim: We aimed to show that autologous serum drop may improve the recovery of patients with dry eye syndrome who did not respond to cyclosporine and lubricants.

Case: A 58-year-old female patient with rheumatoid arthritis for 20 years referred to the cornea department of our clinic with dry eye symptoms. Her best corrected visual acuity was 0.8 in both eyes, slit lamp examination showed intense punctate epitheliopathy (Figure 1), tear film break-up time (TBUT) was measured as 1-2 sec and Schirmer test was 0-1 mm in both eyes, and the other eye examinations were determined normally. The patient was first treated with lubricant tear drops, followed by topical cyclosporine treatment for about one year, but there was no change in symptoms and ocular surface parameters. For this reason, the autologous serum drop (ASD) was suggested to the patient. A significant improvement was observed in the symptoms of the patient who had OSD treatment for 6 months and an evident increase in complaints was occured when the treatment was interrupted. At the last control of the patient, BCVA was 0,9 in both eyes, TBUT was 2-3 sec, Schirmer was 2-3mm, and ther was mild punctate epitheliopathy on slit lamp examination.
\end{abstract}

Conclusion: ASD is an effective treatment option that should be kept in mind when there is no response to lubricants and topical cyclosporine treatment in severe dry eye syndrome cases. Significant reductions were achieved in the symptoms even if there were no expressive changes in the T BUT and Schirmer test results in patients. Patients under treatment of ASD should be closely followed due to contamination and secondary infection.

Keywords: Epitheliotrophic; Immunoregulator; Topical cyclosporine; Antibacterial; antibacterial

Abbrevations: TBUT: Tear Film Break-Up Time; ASD: Autologous Serum Drop; EGF: Epithelial Growth Factor; TGF: Transforming Growth Factor

\section{Introduction}

The tear film layer is critical for corneal and ocular surface health due to its ingredients and antibacterial properties

a) Reduction of epitheliotrophic factors in the dry eye syndrome can lead to complications up to visual loss as a result of impaired integrity of the surface epithelium.

b) Lubricant eye drops moisten the ocular surface but do not contribute to tear components [1].

c) Topical cyclosporin is an immunoregulator that inhibits proliferation of T lymphocytes and interleukin-2 production, and also has an effect of enhancing the tear secretion.

d) One of the treatment options is to use tear drops made from one's own serum (autologous serum drops[ASD]) [1].

In this study, we presented a case of dry eye syndrome which did not respond to topical cyclosporin and lubricants but recovered with autologous serum drop.

\section{Case Report}

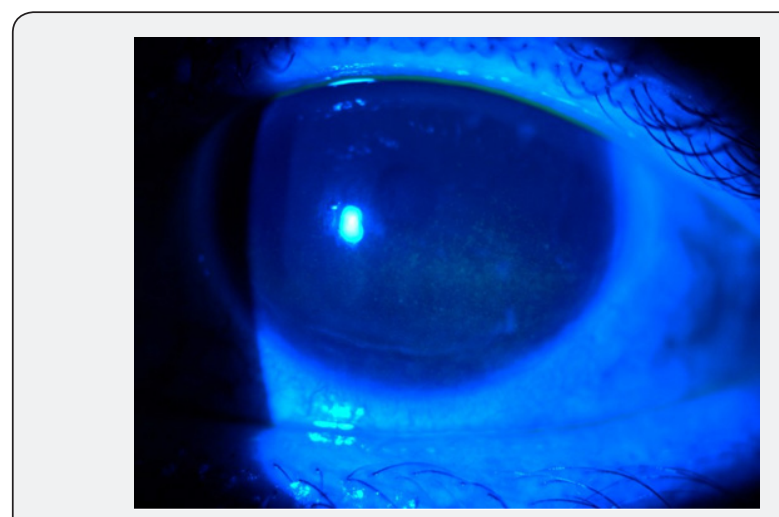

Figure 1: Punctate epitelipoathy before ASD.

A 58-year-old female patient with rheumatoid arthritis for 20 years applied to the cornea department of our clinic with the symptoms of dry eye. Her best corrected visual acuity was 0.8 
in both eyes, slit lamp examination showed intense punctate epitheliopathy (Figure 1), tear film break-up time (TBUT) was measured as $1-2 \mathrm{sec}$ and Schirmer test was $0-1 \mathrm{~mm}$ in both eyes , and the other eye examinations were determined normally.

The patient was first treated with lubricant tear drops, followed by topical cyclosporine treatment for about one year, but there was no change in symptoms and ocular surface parameters. For this reason, the autologous serum drop (ASD) was suggested to the patient. A significant improvement was observed in the symptoms of the patient who had OSD treatment for 6 months and an evident increase in complaints was occured when the treatment was interrupted. At the last control of the patient, BCVA was 0,9 in both eyes, TBUT was 2-3sec, Schirmer was $2-3 \mathrm{~mm}$, and ther was mild punctate epitheliopathy on slit lamp examination. The current treatment protocol of the patient is leflunomide $100 \mathrm{mg}$, preguanil $200 \mathrm{mg}$, methyl prednisolone tablet $4 \mathrm{mg}$ for rheumatoid arthritis; for the dry eye syndrome sodium hyaluronate drop and ASD 5 times daily. No secondary infection was observed during follow-up visits.

\section{Discussion}

The ASD is largely similar with the tear content. The comparison of growth factors and nutrient contents of healthy human serum and tear is shown on (Table 1) [1]. In these contents; EGF (epithelial growth factor), TGF (transforming growth factor) -beta and vitamin $E$ have an accelerating effect on epithelialization. ) Vitamin A, which is found more in serum, is important for the patients that have dry eye syndrome by reducing the squamous metaplasia progression [2]. Serum antiproteases in it provide corneal collagenase inhibition. On the other way, IgG and lysozyme have antibacterial effects [2,3].

Table 1: Comparison of tear and serum components.

\begin{tabular}{|c|c|c|}
\hline $\mathbf{p H}$ & Tear & Serum \\
\hline Osmolarity & 7.4 & 7.4 \\
\hline $\begin{array}{c}\text { Fibronectin (mg/ } \\
\mathbf{m L}\end{array}$ & 298 & 296 \\
\hline İn open eyes & Mar-79 & 300 \\
\hline In closed eyes & $1.177-11.384$ & - \\
\hline EGF (ng/mL) & $0.7-9.7$ & 0.5 \\
\hline TGF-beta (ng/mL) & 10 & 50 \\
\hline Retinol (ng/mL) & $0.4-10.6$ & 55 \\
\hline Vitamin A (mg/mL) & 0.02 & 46 \\
\hline
\end{tabular}

When OSD is being prepared, approximately $450 \mathrm{ml}$ of whole blood is collected by phlebotomy and then allowed to coagulate at room temperature for minimum 2 , maximum 4 hours. The coagulated blood is then centrifuged at $3000 \mathrm{xg}$ for 15 minutes and the supernatant is removed from the precipitate in sterile conditions [3,4]. In RA patients whose fibronectin and TGF-beta concentrations are lower than healthy population, it can be used without dilution [5]. After being placed in the droppers, it can be kept at +4 degrees for 1 month and in the freezer for 3 months at
-20 degrees in a closed form $[3,4]$. The drops should be protected from light as vitamin A deteriorates under the light [1].

The ASD is applied topically in addition to lubricants 4-10 times in a day, in the form of generally accepted usage. The duration of treatment ranges from 1 to 6 months and is adjusted by ophthalmologists [1].

As well as the main indication for the use of ASD is the presence of dry eye syndrome, which is manifested by persistent corneal epithelial disorders, punctate epithelial erosions, filamentous keratitis or neurotrophic ulcers, it has had a broader field of application in from refractive to oculoplastic surgery in recent years [1].

There have been no reports of serious complications due to the use of ASD [6]. There is a risk of contamination in these drops due to high protein content [6]. Prophylactic antibiotic therapy should be given if there is a risk of infection thinking of the time and the additional personnel are necessary for the preparation and the distribution of these drops [7-13].

\section{Conclusion}

ASD is an effective treatment option that should be kept in mind when there is no response to lubricants and topical cyclosporine treatment in severe dry eye syndrome cases. Significant reductions were achieved in the symptoms even if there were no expressive changes in the T BUT and Schirmer test results in patients. Patients under treatment of ASD should be closely followed due to contamination and secondary infection.

\section{References}

1. Utine C, Akpek E (2010) Use of autologous serum eye drops in ophthalmology literature: expanding indications: review. Turkiye Klinikleri J Ophthalmol 19(3): 161-170.

2. Tsubota K, Goto E, Fujita H, Ono M, Inoue H, et al. (1999) Treatment of dry eye by autologous serum application in Sjögren's syndrome. Br J Ophthalmol 83(4): 390-395.

3. Berman MB (1975) Collagenase inhibitors: rationale for their use in treatng corneal ulceration. Int Ophthalmol Clin 15(4): 49-66.

4. Geerling G, Maclennan S, Hartwig D (2004) Autologous serum eye drops for ocular surface disorders. Br J Ophthalmology 88(11): 14671474.

5. Bradley JC, Bradley RH, McCartney DL, Mannis MJ (2008) Serum growth factor analysis in dry eye syndrome. Clin Experiment Ophthalmol 36(8): 717-720.

6. Kaya FS, Akova YA (2012) The Effect of Autologous Serum Eye Drop Application on Epithelization in the Treatment of Various Ocular Surface Disorders and its Safety: Original Article TJO 42(5): 336-341.

7. Özdemir FA, Erkam N, Aksu Ö (2005) Autologous serum application in dry eye. MN-Opthtalmology 12(1): 58-62.

8. Tsubota K (1998) Tear dynamics and dry eye. Prog Retin Eye Res 17(4): 565-596.

9. Tatlipinar S, Akpek EK (2005) Topical ciclosporin in the treatment of ocular surface disorders. Br J Ophthalmol 89(10): 1363-1367.

10. Pancholi S, Tullo A, Khaliq A, Foreman D,Boulton M (1998) The effects of growth factors and conditioned media on the proliferation of 
human corneal epithelial cells and keratocytes. Graefes Arch Clin Exp Ophthalmol 236(1): 1-8.

11. Wilson SE, Liang Q, Kim WJ (1999) Lacrimal gland HGF, KGF, and EGF mRNA levels increase after corneal epithelial wounding. Invest Ophthalmol Vis Sci 40(10): 2185-2190.
12. Smolin G, Okumoto M, Friedlaender M (1979) Tretinoin and corneal epithelial wound healing. Arch Ophthalmol 97(3): 545-546.

13. Liu L, Hartwig D, Harloff S, Herminghaus P, Wedel T, et al. (2005) An optimised protocol for the production of autologous serum eyedrops. Graefes Arch Clin Exp Ophthalmol 243(7): 706-714.

\section{Your next submission with Juniper Publishers will reach you the below assets}

- Quality Editorial service

- Swift Peer Review

- Reprints availability

- E-prints Service

- Manuscript Podcast for convenient understanding

- Global attainment for your research

- Manuscript accessibility in different formats

( Pdf, E-pub, Full Text, Audio)

- Unceasing customer service

Track the below URL for one-step submission https://juniperpublishers.com/online-submission.php 